Vol. XXIII No 12017

\title{
EU POLICY INITIATIVES IN THE MEDITERRANEAN REGION
}

\author{
Mariya HADZHIPETROVA-LACHOVA \\ "Neofit Rilski" South-West University, Blagoevgrad, Bulgaria \\ maria.hadzhipetrova@gmail.com
}

\begin{abstract}
The article traces the various stages in the development of EU-the Mediterranean region as well as the EU policy initiatives in the Mediterranean region. The very history of the European unification gives hope that by gaining experience in overcoming the difficulties of diverse nature, the Union will be able to "reset" relations with its Mediterranean partners, basing them on new principles and values.
\end{abstract}

Keywords: EU, Mediterranean region, Euro-Mediterranean Partnership (Euromed), European Neighbourhood Policy, Union for the Mediterranean (UfM)

\section{Introduction}

At present, the Mediterranean region covers 26 coastal countries that share its geographical position and historical past, yet they are divided into rich and democratic North and poor and politically unstable South. The Southern Mediterranean is characterized by underdeveloped infrastructure, low-skilled labor and high unemployment. Challenges such as migration, terrorism, organized crime, human trafficking and environmental issues can hardly be overcome by any one country alone, which promotes regional cooperation and initiatives of the EU regarding the Mediterranean region.

\section{Stages in the development of EU -} Mediterranean region relations

The beginning of the relations between the EU and the Mediterranean region could be found at the outset of the creation of the European Communities (EC) in 1950s. The Treaty of Rome establishing the European Economic Community in 1957 [1] allows the EC Member States to orient themselves, if not yet to a common policy, then to a single basis of their policies towards the Mediterranean. The task is gradually replacing the individual policies of Member States to the Mediterranean region with a common approach, with a general policy of the Union.

The second phase of this policy is associated with the initiated in 1972 Overall Mediterranean Policy (OMP) of EC. The comprehensive dimension of the Mediterranean policy is aimed at "coastal countries of the Mediterranean (including Jordan) which wish or would like to maintain a special relationship with the Community." [2]

Another initiative to build closer cooperation between the two shores of the Mediterranean is the Euro-Arab dialogue from 1973 till 1990. The idea was launched in 1970 by France, which proceeds from its foreign policy aimed at the Arab world. [3] The foundations of cooperation between the League of Arab States and the EC are already present and economic and political cooperation in the field of agriculture, industry, science, culture, technology, 
finance and public infrastructure is established. [4]

So in 1970s relations were developing with the countries of North Africa and the Middle East most intensively. During this period there were implemented two approaches to the region - the existence of still in force bilateral agreements between Member States and the Mediterranean countries and the emergence of the first joint EU agreements with individual states in the region.

As a third stage of the Mediterranean policy of the EC (later EU) it is determined the time from late 1980 s to mid 1990 s of the $20^{\text {th }}$ century. During this period the southern extension of EC (Greece, Spain and Portugal) was prepared and implemented. This expansion had a negative impact on exports from the Mediterranean to the EC because of the similarity of this export production, mainly of agricultural products and citrus fruit in the new countries. Overall in EU's policy there could be observed a gradual transition from a heterogeneous approach to a more constructive global concept with respect to the Mediterranean region.

Especially important for the modern formation and development of the EU common foreign policy towards the Mediterranean region is the second half of 1990s. It is in this period that the alignment of that policy takes place in accordance with both the modern development of the EU and the challenges of the incoming new century. Undoubtedly a major role in this played the conducted in November 1995 in Barcelona Conference of Foreign Ministers of EU and the Mediterranean countries. That was the beginning of a new strategy of partnership between them, known as the "Barcelona Process" (BP) or the EuroMediterranean Partnership (EUROMED).

\section{EU initiatives towards the Mediterranean}

The main objective of the Barcelona Declaration, signed by the then 15 Member States of the EC and the 12 countries of the southern Mediterranean is the creation of a new regional system of relationships aimed at economic growth and liberalization in the partner countries and the establishment of a long-term political and social stability and security within the new European concept of international cooperation.

The conference formulated a program of cooperation in three main areas:

- Defining a common area of peace and political stability through dialogue in the field of security. The goal is to build partnerships between participants in BP on security issues. Respect for human rights, democratic values and respect for social pluralism within countries themselves, as well as ensuring the territorial integrity, peaceful conflict resolution and respect for international norms on arms control are some of the requirements contained in a voluminous catalog. [5]

- Building a zone of shared prosperity through an economic and financial partnership and the gradual establishment of a free trade zone. According to the measures provided for in this direction, economic relations between the participating countries should be intensified. [6]

- Bringing nations together through cooperation in social, cultural and humanitarian spheres in order to promote understanding between cultures and civil societies. The dialogue and mutual respect between cultures and religions should be encouraged, and opportunities for training and education - improved. [7]

The three areas of cooperation that BP covers cannot be considered separately. Trade, economic assistance and immigration of the population are interrelated and the political stability and security in the region depend on the successful resolution of socio-economic problems in individual Mediterranean partner countries.

The regional cooperation is one of the most innovative aspects of BP as it covers and superimposes three dimensions of cooperation, namely cooperation in the field 
of economics, politics and culture. The aim is to develop not only North-South relations, but also South-East relations.

The existing economic disparities between Europe and the Eastern Mediterranean and creates a structure of asymmetric interdependence and increases the dominant role of the EU in all negotiations on the Euro-Mediterranean partnership. Between partner countries bilateral relations continue to dominate, although the Barcelona Declaration gives priority to multilateral cooperation. The prevalence of bilateral relations in the Euro-Mediterranean policy creates artificial obstacles to the entry of the southern Mediterranean countries as a single economic unit and allows the EU to use its advantages as the most powerful partner and a major donor.

With the complexity of the international situation (crisis in Iraq (2005), another outbreak of violence in the Middle East, the spread of terrorism and its impact on societies) at the beginning of the new millennium and faced with its greatest territorial expansion, the EU seeks new solutions to structural, organizational and problematic challenges it faces. In this complex context, the Union launched the European Neighborhood Policy (ENP) in its two dimensions - east (Eastern Europe and then South Caucasus) and south (countries of North Africa and the Middle East).

The new Neighborhood Policy is aimed at building a unified format for European relations with the new southern and eastern neighbors with their possible integration into the European single market but also to establish more active relations between the $\mathrm{EU}$ and its neighbors. Regarding the Mediterranean states ENP should reinforce existing forms of cooperation, accelerate regional and subregional integration processes and ensure the gradual establishment of the EU internal market, in the core of which are the four freedoms: free movement of people, goods, services and capitals. An important role in the new policy is attributed to political factors and safety issues in the Mediterranean region, as well as the liberalization of trade and economic development. It, along with Euromed, covers the political dialogue, economic cooperation and trade, migration and the problems associated with it, regional and sector focus on partnership, cooperation in the financial, energy and information fields. [8] In this connection, the scope of the ENP in the southern dimension appears as a new policy tool that confirms, supports and complements the Euro-Mediterranean Partnership in 1995.

What is typical of the neighborhood policy is that it does not envisage EU membership; it envisaged privileged relations based on recognition of common values - democracy and human rights, rule of law and good governance, market economy and sustainable development. Within privileged relations the neighboring beneficiary countries take advantage of the cooperation in trade, industry, agriculture, energy security, transport, science and research, education, culture, etc. This basic characteristic distinguishes it from the enlargement policy. However, the neighborhood policy is similar to the one of expansion in that it applies the principle of conditionality. According to this principle, neighboring countries should carry out conditions and reforms in order to prove their loyalty to shared values and thereby gain access to the financial instrument of EU cooperation. This principle was advocated in the Euro-Mediterranean cooperation, but in practice it was not applied. The impact of the principle of change led to the Arab Spring in the Mediterranean countries and this was a clear sign that the neighborhood policy needs revision.

The latest EU initiative in the Mediterranean region is associated with the idea of the French President François Sarkozy to establish a Mediterranean Union. The form in which it was launched in January, however, excludes the participation of the EU or provides for a minimum of its participation. Therefore, the initiative received a negative response from 
a number of leading figures in the EU and Sarkozy was forced to make changes so that it does not completely fail. On December 20, 2007 the Government leaders of France, Italy and Spain met in Rome and adopted a joint document entitled "Call of Rome". It outlines the main guidelines of the project and makes adjustments to the name. [9]

"The Mediterranean Union" (UM) becomes the "Union for the Mediterranean" (UfM). By the linguistic and stylistic change of the name the importance of the EuroMediterranean Partnership is reaffirmed and skeptics in the project soothe themselves with the fact that a new regional organization will not be created. At the same time in the place of the initial idea for a closed Mediterranean club, a different pan-European perspective for the Mediterranean is being formed. Another distinctive feature of the Union for the Mediterranean is that it adds to the three main areas of BP (economy and trade, security, culture and humanitarian issues) a fourth direction - cooperation in justice and home affairs. If within BP, the only structure, decision maker and the one funding projects is the EU, in the Union for the Mediterranean there is offered a copresidency for a period of two years (at the moment the EU is represented by the President of the EU, Head of the European External Action Service and President of the EC while the Mediterranean countries present its chairperson on the principle of consensus start). In addition, there was created a Permanent Secretariat (based in Barcelona), which deals with the selection and analysis of the projects needed for the region. [19] In this sense, the new alliance brings two major features that were lacking in previous initiatives, namely joint responsibility and joint decision constituting a qualitative step forward in the quest for cohesion of the countries. What is also new in the Union is that the cooperation is built around specific projects within the problematic issues and has the status of an important, but "complementary", chapter of BP. At the summit in Paris six key strategic sectors for cooperation are defined - civil protection; construction of marine and land infrastructures; environmental cleansing of the Mediterranean; development of alternative energy sources (particularly solar energy); development of higher education and scientific research; business development through a mechanism for promoting small and medium enterprises.

Thus, the new alliance promotes multilateral and regional cooperation, which should complement EU bilateral relations with Mediterranean partners taking place within the framework of the Association Agreements. This also applies to the Action Plans of the ENP. The activity of the Union for the Mediterranean will not depend on the EU policy on enlargement, negotiations for EU accession and preaccession process. The EU initiative gives a new impetus to BP on three main areas: 1) raising the political level of the EU's relations with Mediterranean countries, 2) ensuring joint projects and thus strengthening the multilateral relations and 3) creating more specific and transparent relations through additional regional and subregional projects. The launched in 2008 project "Union for the Mediterranean", which may reasonably be considered as a supplement and continuation of $\mathrm{BP}$, has been built with the active participation of the EU and its institutions.

\section{Conclusion}

As a result of the shown by Sarkozy activity, the EU currently has a total program of initiatives - the EuroMediterranean Partnership, European Neighborhood Policy in its Southern dimension and the Union for the Mediterranean. Despite the nearby nature of these initiatives, in many ways they are complementary, but different as well. Initiatives have been undertaken at different stages of development of the EU - the Mediterranean region. Objectives and mechanisms used to implement them, despite being close, do not in any case 
overlap. This to some extent is due to the

diverse challenges facing the EU in terms of its policy conducted in the Mediterranean region.

\section{References}

[1] Договор за създаване на Европейска икономическа общност от 25 март 1957 г., изд. 1994, c. 387. (Treaty establishing the European Economic Community on March 25, 1957 (1994), p. 387.)

[2] $J O \mathrm{n}^{\circ} \mathrm{C} 19,1^{\text {er }}$ mars 1972, p. 15 , point $\mathrm{n}^{\circ} 4$.

[3] Saint-Prot, Charles, La politique arabe de la France, Observatoire d'études géopolitiques, 7/2007.

[4] Bat Yé'Or, Le dialogue Euro-Arabe et la naissance d'Eurabia, L'Observatoire du monde juif, 03/12/2002.

[5] Malmvig, Helle (2005) Security through Intercultural Dialogue? Implications of the Securitization of Euro-Mediterranean Dialogue between Cultures. Mediterranean Politics, Vol. 10, No. 3, 349-364.

[6] New Neighbourhood Policy Strategy Paper. Doc COM (2004) 373 final 12.05.2004. Commission of European Communities. Brussels, 2004.

[7] Stetter, Stephan (2015). The Politics of De-Paradoxification in Euro-Mediterranean Relations: Semantics and Structures of 'Cultural Dialogue'. Mediterranean Politics, Vol. 10 (3), 331-348.

[8] Kiryakova-Dineva (2016). Mezhdukulturen dialog v turizma. University Press Neofit Rilski: Blagoevgrad (in Bulgarian: Кирякова-Динева, Теодора. Междукултурен диалог в туризма. Университетско издателство „Неофит Рилски”: Благоевград).

[9] Schmid, Dorothée, (mars avril 2009), Dossier la Méditerranée. Du Processus de Barcelone à l'Union pour la Méditerranée: changement de nom ou de fond?, Questions internationales, Institut Français des Relations Internationales, p. 3.

[10] http://www.diplomatie.gouv.fr/fr/IMG/pdf/Declaration_commune_UPM_bis.pdf. 